\title{
A HOLTFA ÉS EGYÉB ERDŐÖKOLÓGIAI TÉNYEZŐK JELENTŐSÉGE A DENEVÉREK SZÁMÁRA
}

\author{
Dobrosi Dénes \\ Jász-Nagykun-Szolnok Megyei Kormányhivatal
}

\begin{abstract}
Kivonat
2013-2015 között az Alföldön és a Börzsönyben a saját fejlesztésű ultrahangrögzitő és elemző módszerünk segítségével összesen 685 felmérési ponton 82870 db rögzített hangfájlból 23 denevérfajt sikerült beazonositanunk. A felmérési pontokon az erdők egyszerủ élöhelyi értékelését is elvégeztük, továbbá a holtfa mennyiségét is megbecsültük szemrevételezéssel. Az így kapott erdő természetességi mutatók és a denevérek aktivitása között igyekeztünk kapcsolatokat keresni. Homogenitás vizsgálattal kimutattuk, hogy a természetvédelmi szempontból kiemelt jelentőségü denevér-fajcsoportok egyedeinek éjszakai aktivitása pozitív korrelációban van az élőhelyek ökológiai minőségével és a holtfa mennyiséggel.
\end{abstract}

Kulcsszavak: denevér, holtfa, élöhely, egyedsürüség, ultrahang rögzités, hangelemzés.

\section{IMPORTANCE OF DEAD WOOD AND OTHER FOREST HABITAT VARIABLES FOR THE BATS}

\begin{abstract}
Between 2013 and 2015 we managed to identify 23 bat species from 82870 audio files recorded at 685 sites in the Alföld and Börzsöny (Hungary) by the ultrasound recording and analysing method we developed ourselves. We prepared a basic forest habitat assessment at each site and estimated the amount of the deadwood. We were aiming to find a connection between the naturalness of the study sites and the activity of the bats. Using a homogeneity examination, we found that the overnight activity of the significant groups of bat species was in positive correlation with the ecological quality of their habitat and the amount of deadwood.
\end{abstract}

Keywords: words: bat, deadwood, habitat, density, ultra sound recording, sound analysis.

\section{BEVEZETÉS}

Az erdő a denevérek számára búvóhely és táplálkozó terület is egyben. A legtöbb hazai denevérfaj nappal faodvakban, fatörzsek repedéseiben és kéreg alatt pihen, sőt kölykeit is itt neveli fel. Vannak azonban olyan denevérfajok, amelyek elsősorban épületekben vagy 
barlangokban tanyáznak, ám éjszaka ezek a fajok is felkeresik az erdőket, hiszen a leggazdagabb táplálékforrás, a legtöbb rovar itt található. Nyugodtan állíthatjuk, hogy a hazai denevérfajok nagyon kötődnek az erdőkhöz, legyen az sík-, domb- vagy hegyvidéki fekvésü. Minél természetesebb az erdő, általában annál bőségesebb a rovarokból származó táplálékkészlet a denevérek számára (Magura és mtsai 2000; Ódor 2014). Vizsgálataink célja az volt, hogy megtudjuk, milyen erdőkben fordulnak elő leggyakrabban a denevérek. Feltételeztük, hogy ahol sok a táplálék, ott nagyobb a denevérek aktivitása, egyedsűrüsége. Egyszerüsített hipotézisünk szerint az erdő természetességi mutatója és a denevérek aktivitása között szoros kapcsolat van. Tanulmányunk során ennek az állításnak a valódiságát szerettük volna bizonyítani vagy elvetni.

\section{ANYAG ÉS MÓDSZER}

\section{Az adatgyüjtés módszere}

A terepi vizsgálatok révén egy olyan adatbázis felépítésére törekedtünk, amely különféle erdőkben, nagyszámú mintavételi ponton, a denevérek mozgásintenzitását, az egyes élöhelyek "hasznosításának" aktivitását mért adatokkal, reprezentatív módon jellemzi. A denevérek zavarásra érzékeny, éjszaka aktív állatok, ezért olyan mintavételi módszert kellett választanunk, amely nem befolyásolja az állatok viselkedését. Hálózással vagy egyéb módon történő élve befogás szóba sem jöhetett, mert ilyen módszer mellett az állatok könnyen megijednek, repülési útvonalaikat megváltoztatják, s így akár a kolóniák ideiglenes elköltözésével is számolni kellett volna. Mivel a denevérek röptükben parányi megszakításokkal, folyamatosan adnak ki ultrahangokat, ezért azt a módszert követtük, hogy ultrahang-detektorok segítségével mértük a denevérek aktivitását az erdők adott pontjain. Az ultrahang-detektorokat a bőregerek egyáltalán nem érzékelik, így a legkisebb zavarás nélkül tudtuk őket vizsgálni.

A denevérek mozgásintenzitásának mérésére és a fajhatározásra a saját fejlesztésű denevérdetektorainkat használtuk. A müszereket a fák ágaira akasztottuk fel 5-8 méter magasságba, úgy hogy azok az ott elrepülő denevérek hangját jól fel tudják venni. Egy mintavételi helyen 1, esetleg 2 éjszakán át müködtettük az eszközöket, majd az akkumulátoraik töltésére beszedtük, $s$ a következő alkalommal újabb helyeken raktuk ki. A saját fejlesztésü detektorainkat kezdetben folyamatosan 1db IBATS detektorral, később $1 \mathrm{db}$ Pettersson D500x típusú denevérdetektorral is teszteltük.

Minden elrepülő denevér ultrahangokat bocsát ki, s ezeket a rezgéseket a detektoraink az erős hangokat adó fajok esetében akár már 20-50 méter távolságból érzékelik, a gyengébb jeleket kibocsátó fajok esetében a hatótávolság mintegy 10 méterre csökken. A detektorok a denevérek ultrahangját érzékelve, a hanghullámokat memóriakártyájukon hangfájlként rögzítették. 
Egyszerre általában 10-20 db detektort helyeztünk ki egy mintahelyen, de esetenként 30 $\mathrm{db}$ dolgozott egyszerre. A detektorok azonos érzékenységre voltak állítva, így a denevérhangokat rögzítő hangfájlok száma mindig utalt az erdőben mozgó egyedek aktivitására, s ezzel összehasonlító elemzésre is alkalmassá vált a módszer.

A detektorokat legfőképpen olyan helyekre raktuk ki, ahol jelentős esélye volt annak, hogy ott denevérek röpködjenek. Hosszú évek kutatási tapasztalatai alapján rájöttünk arra, hogy nagyon sürü, zárt erdőállományokban a denevérek ritkán vadásznak. Táplálkozni szívesebben keresik fel az erdőn belül azokat a szabad légi folyosókat, ahol egyrészt a rovarok is előszeretettel rajzanak, továbbá ott könnyebb is őket elkapniuk a denevéreknek. Ilyen légcsatornák a patakvölgyek ligetei, az erek, vízfolyások fölötti szabaddá váló légterek, a nyiladékok folyosói, a kidőlt vagy kivágott fák helyén kialakuló lékek, tisztások, a termőhelyi okból záródáshiányos erdőrészek és az erdőben kialakuló mocsarak, időszakos vízállások, dagonyák felnyíló foltjai. A denevérek ezeket a légifolyosókat az éjszaka folyamán rendszeresen használják, időröl-időre ismételten meglátogatják, $s$ ahol bő rovartáplálékot találnak, ott hosszabban elidőznek és ez által nagyobb egyedsürüségben vannak jelen.

Az időnyújtásos ultrahang-detektor az egyes hangokat külön fájlokba menti. A detektor hangsávja $10-140 \mathrm{kHz}$, a hangrögzítés bitrátája $64 \mathrm{kHz}$, a müszer frekvenciaszürőt nem használ. Egy rögzített hangfájl 826 ms időintervallumra jutó hangokat tartalmaz, ami ideális a különböző denevérfajok fajhatározására. A különböző denevérfajok elkülönítésére a szintén saját fejlesztésủ számítógépes programot használtuk. A fajhatározásnál a legföbb paraméterek a hanggörbe formája, maximális és minimális frekvenciaértéke, az aktív hangtartomány hossza és a hangimpulzus legerősebb jelének frekvenciaértéke, de ezeken túl több egyéb faj specifikus jellemzőket is vizsgálunk a fajhatározás során. A fajcsoportokra jellemző határozóbélyegeket szakirodalmakból vettük át (Ahlén1981, Ahlén \& Baagoe 1999, Barataud 2015, Dietz \& Kiefer 2014, Fenton\& Bell 1981, Griffin et al. 1960, Jones 1999, Obrist et al. 2004, Russo \& Jones 2002, Vaughan et al. 1997, Waters \& Jones 1995), illetve részben saját gyüjtésekre és megfigyelésekre alapoztuk. Az egyes paramétereket a számítógépes programunk olvassa be és a változók segítségével egyezőségi valószínűség lévén azonosítja be a hangokat fajra, fajcsoportra vagy nemzetségre. Ahol az egyezési valószínüség $70 \%$ alatti volt, ott a beazonositást a hanggörbe ránézéses vizsgálatával pontosítottuk. Ismert tény, hogy nem minden hang esetében lehet teljes bizonyossággal a denevérfajt meghatározni (Csősz \& Szodoray 2009, Szőke \& Estók 2013, Zsebők 2003). Egyes fajpárokon vagy fajcsoportokon belül a fajok elkülönítése többnyire csak a tipikus hangok esetében lehetséges (Entwistle et al. 1996, Estók \& Görföl 2009, Jensen \& Miller 1999, Jones1995, 1996, Kalko \& Schnitzler1989, Zsebők et al. 2012). Ez pedig a gyüjtött hanganyag erőteljes szelektálását okozta volna, ezért a hangokat a biztosabb beazonosítás érdekében a néhány fajból álló fajcsoportokba soroltuk be. Jelen tanulmány esetében a hanganyag teljes kiértékelése, az adatbázis feltöltése a Myotis, a Barbastella, a Plecotus, a Pipistrellus és az általunk „légivadász"-nak nevezett fajcsoport elkülönitése révén jött létre. Az adatfeldolgozást a fajcsoportok adatainak statisztikai elemzésével végeztük el, a teljes hanganyag faji szinten 
történő beazonositására ezért nem volt szükség. Az egyes fajcsoportok jellemzését a következő alfejezetben részletezzük.

A denevérek röptükben folyamatosan tájékozódó ultrahang impulzusokat bocsájtanak ki, de időközben ettől eltérő, úgynevezett „szociális hangokat” is hallatnak. A szociális hangok nem hasonlítanak a tájékozódó hangimpulzusokhoz, s habár ezek is faj specifikusak, ezeket a kommunikációs hangokat nem vettük be az adatbázisba. A szociális hangok között, illetve közvetlen előtte vagy utána szinte kivétel nélkül mindig tájékozódó ultrahangokat is kiáltanak az állatok, ezért nem láttuk célszerünek a szociális hangokat külön értékelni és számba venni.

Helyenként a keskeny erdei nyiladékokra és vízfelületekre mozgásérzékelővel kombinált automatikus kioldású fényképezőgépeket helyeztünk ki. A repülő denevérekről készített képek jelentős része fajhatározásra is alkalmas volt, s olyan fajok esetében, ahol a hang alapján történő faj szintü határozás nem volt biztos, ott ez a módszer a faj kérdésének tisztázásra adott lehetöséget.

\section{Az adatgyüjtés helye és ideje}

A denevérek hangjait 3 éven keresztül (2013-2015 között), kora tavasztól késő őszig a denevérek aktív időszakában gyüjtöttük. A denevérfajok többsége fagypont feletti éjszakákon már akár március elején elhagyja telelöhelyét, kijár táplálkozni, s elindul a nyári tanyahelye felé, vagyis megkezdi a vonulását. Általában április közepén népesülnek be a nyári kolóniákkal a területek, az ezt megelőző időszakban gyüjtött adatokat nem tekinthettük reprezentatívnak, ezért tanulmányunkban ezeket a kora tavaszi adatsorokat nem szerepeltettük. Az őszi vándorlás augusztus 20-a után kezd intenzívvé válni, ezért a síkvidéki területeken ezt követően gyüjtött adatsorokat szintén kivettük az adatbázisból. A denevérfajok többsége szeptember végén már telelöhelyein van, s hüvösebb éjszakákon egyes fajok egyedei akár ki sem repülnek táplálkozni, ezért a hegyvidéki területeken a szeptember 19-ét követő adatsorokat szintén kihagytuk a feldolgozásból. Megfigyeltük, hogy olyan éjszakákon, amikor több órán át tartó csapadék esik, erős szél fúj, vagy hidegfront miatt hirtelen lehülés tapasztalható, a denevérek aktivitása visszaesik, akár annyira is, hogy egész este ki sem repülnek pihenöhelyeikröl. Az ilyen szélsőségesnek mondható éjszakákon mért adatokat nem tekintettük reprezentatívnak, ezeket szintén nem szerepeltetjük az adatbázisban.

A vizsgálatokba alföldi és a hegyvidéki területeket egyaránt bevontunk. Kistájakba sorolva a következő helyeken kutattunk: Kis-Sárrét, Körösmenti-sík, Jászság, Hatvani-sík, Solti-sík, Kiskunsági-homokhát, Pilis-Alpári-homokhát, Dél-Tisza-völgy, Csepeli-sík, DélNyírség, Szatmári-sík, Északkelet-Nyírség, Közép-Nyírség, Délkelet-Nyírség, Alsó-Ipolyvölgy, Központi-Börzsöny, Börzsönyi-peremhegység, Börzsönyi kismedencék, Nógrádi-medence, Visegrádi-Dunakanyar, Kosdi-dombság.

Összesen 685 mintavételi helyszín adatai szerepelnek az adatbázisban. A síkvidéki területeken föleg ártéri erdőket (hazai nyárasokat és füzligeteket), homoki kocsányos tölgye- 
seket, a hegyvidéken leggyakrabban bükkösöket, kocsánytalan tölgyeseket, patakparti égereseket és füzeseket vizsgáltunk. Elsősorban a viszonylag jó ökológiai állapotú erdei élőhelyeket igyekeztünk felkeresni, de a mintavételbe bevontuk a különböző vágásterületeket, a fiatalosokat és a rontott erdőket, továbbá az őshonos és az idegenhonos fafajokból álló erdőket is, hogy egyaránt képet kapjunk a jó és a kevésbé jónak ítélt élöhelyek denevérlátogatottságáról.

\section{A denevérek fajcsoportokba sorolása}

A denevérek által kibocsátott ultrahangok faji szinten történő beazonosítása a jelenlegi ismereteink mellett nem minden esetben lehetséges (Szőke \& Estók 2012). Vannak olyan fajok, melyek ultrahang impulzusai igen hasonlóak. Ráadásul az egyes fajok sem azonos formájú hangokat produkálnak, más a hangja az egyednek, ha nyitott területen repül, s más, ha akadályokkal nehezített sürüben. Megváltoztatja a hangját akkor is, ha több denevér egy légtérben vadászik, különösen akkor, amikor fajtársaival találkozik. Az egyes fajok határozásának bizonytalansága miatt éppen ezért tanulmányunkban olyan fajcsoportokat hoztunk létre, amelyekbe történő besorolás már megfelelő biztonsággal elvégezhető. Ezen fajcsoportok között a különbség már jelentős mértékü, melyeket az alábbiakban mutatunk be.

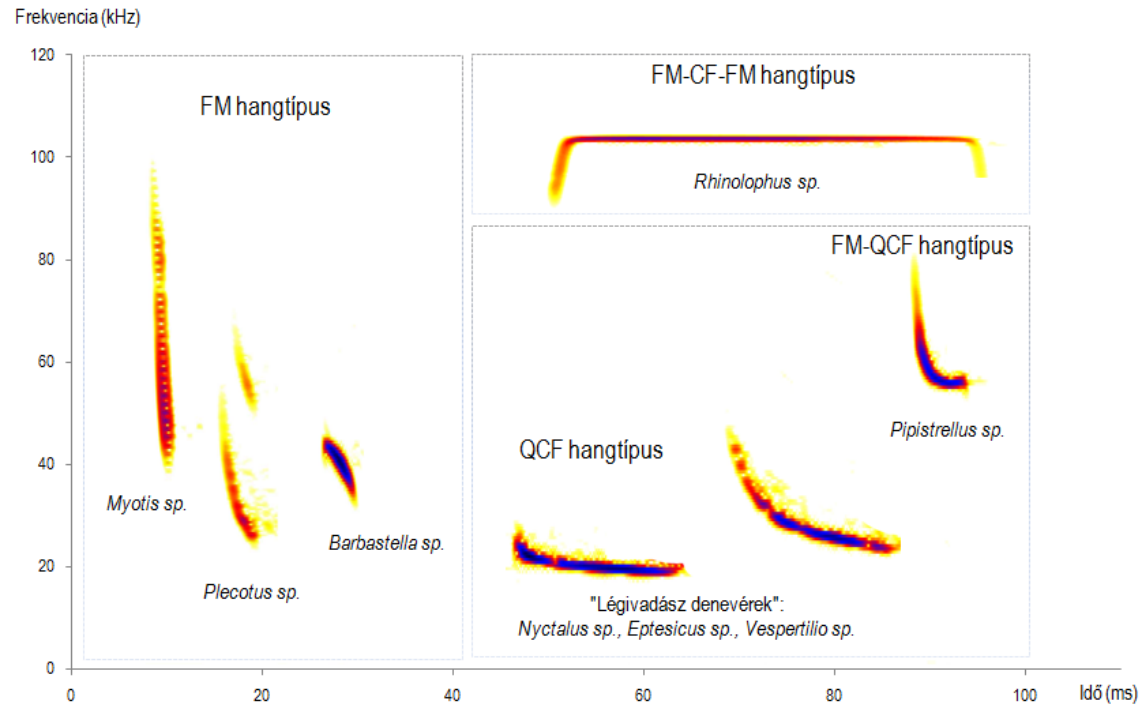

1. ábra: A denevérek fajcsoportokba sorolása az ultrahang típusok elkülönitésével, spektrogram ábrázolással (csak a vizsgálataink során detektált fajcsoportok szerepelnek az ábrán).

Figure 1: Classification of species group based on their ultra sound (only the species groups recorded during our study are included). 
A denevérek által kibocsátott ultrahangjeleket több típusba sorolhatjuk (Vaughan et al. 1997; Dietz \& Kiefer 2014).

A denevérek ultrahangjuk frekvenciáát hirtelen képesek változtatni úgy, hogy közben a jel folytonos. Ezt modulációnak nevezzük. Olyan hang, ahol a frekvenciaváltozás időben egyenletes és nincs állandó frekvencián kitartott szakasz, azt frekvenciamodulált, FM (frequency modulated) hangtípusnak nevezzük. Az FM hangtípus esetén a frekvencia rövid időn belül, magas értékröl alacsonyra zuhan (lásd 1. ábra bal oldali szektor).

\section{a) FM típusba tartozó denevércsoportok}

\section{Myotis csoport:}

Az induló hang magas frekvenciájú, minimum $56 \mathrm{kHz}$. A gyorsan modulált hang végső frekvenciája $49 \mathrm{kHz}$ alatt van, a maximum és a minimum hangok között több mint $30 \mathrm{kHz}$ különbség mutatkozik.

\section{Plecotus csoport:}

Az induló hang $56 \mathrm{kHz}$ alatti, a moduláció pedig nem olyan gyors, mint a Myotis csoportnál, ezért a spektogram görbe nem oly meredek, mint amilyen a Myotis fajoknál. A befejező, legalacsonyabb frekvencia lehet akár $17 \mathrm{kHz}$ mélyen is. A hang maximuma és minimuma között több mint $20 \mathrm{kHz}$ érték szerepel. A frekvenciamoduláció a jel végére gyengül, ezért a görbe kissé ellaposodik. A Plecotus fajok egyedei nagyon gyakran, mint ahogyan ez az 1. ábrán is látható, a jel lecsengése előtt „másik szólamban” egy maga-sabb frekvenciájú, általában kisebb hangerejü, szintén frekvenciamodulált hangot is adnak.

\section{Barbastella csoport:}

Viszonylag szűk frekvenciatartomány jellemzi egy-egy impulzusát. Gyakran a cirrentéseit kis szünetekkel ismételgetve, hol alacsonyabb, hol magasabb frekvencián felváltva variálja, ettől lesz olyan jellegzetes „talicskakerék nyikorgó” hangja. Egyetlen hangimpulzusának frekvenciatartománya $20 \mathrm{kHz}$-en belül van. A frekvenciamoduláció a jel végére gyakran felgyorsul, ezért ilyenkor a görbe picit púposodik.

\section{b) FM-CF-FM típusba tartozó denevércsoport}

Rhinolophus csoport:

Az 1. ábra jobb felső szektorában elhelyezkedő FM-CF-FM hangtípusra jellemző, hogy a denevér viszonylag hosszú ideig állandó frekvencián (constant frequency $=\mathrm{CF}$ ) tartja a jelet, melyet egyébként szabályos időközönként megismétel. Ez a konstans frekvencia magas, minden hazai faj esetében $75 \mathrm{kHz}$ fölött van. Az állandó frekvenciájú tartomány előtt és 
után is egy rövid ideig tartó frekvenciaváltás a jellemző. Ez a frekvenciamoduláció a konstans jel elött frekvenciaemelkedést, a jel végén pedig frekvenciacsökkenést mutat, a hang erőssége általában kisebb, mint az állandó frekvenciájú hangszakaszé. A hangformák változása révén, a rövidítéseket használva, ezt FM-CF-FM jeltípusnak nevezzük.

\section{c) QCF és FM-QCF típusba tartozó denevércsoportok}

Az 1. ábra harmadik, jobb alsó szektorában két hangtípust láthatunk, melyek között tulajdonképpen nincs átmenet, a középső hang akár az egyik, akár a másik hangtípusba besorolható. Határozás szempontjából nincs lényege annak, hogy az átmeneti formát a kettő közül melyik hangtípusba soroljuk. Az alsó, vagyis az alacsonyabb frekvenciájú hangok majdnem állandó frekvencián szól (quasi constant-frequency), ezért ezt a hangformát QCF hangtípusnak nevezzük. A felső hangok hirtelen modulációval indulnak, majd kvázi konstans hangszakaszban végződnek (frequency modulated - quasi constant-frequency). A felső hangtípus jele FM-QCF.

\section{Légivadász csoport:}

A kvázi konstans frekvencia (QCF) és a frekvenciamodulált hanggal induló, majd kvázi konstans frekvenciával befejeződő (FM-QCF) hangtípus egyaránt jellemző rájuk. A legalsó frekvenciaérték mindig $30 \mathrm{kHz}$ alatt van. A hangimpulzusok általában hosszúak, $5-25 \mathrm{~ms}$ ideig tartanak, csak a felfedezett prédához közeledve kezdi el rövidíteni és süríteni a jeleket a denevér. A "Légivadász” fajcsoportba a Vespertilio murinus továbbá a Nyctalus és Eptesicus fajok tartoznak.

Pipistrellus csoport:

Frekvenciamodulált hanggal induló, majd kvázi konstans frekvenciával befejeződő (FMQCF) hangtípus a jellemző rájuk. Előfordul időnként náluk a szimplán QCF hangtípus is. A legalsó frekvenciaérték mindig $30 \mathrm{kHz}$ fölött van. A hangimpulzus közepesen hosszú, általában 3-9 ms között van, de nyilt légtérben elérheti akár a 14 ms-ot is.

\section{AZ ADATOK FELVÉTELE ÉS KIÉRTÉKELÉSE}

Minden mintavételi ponton a közvetlen környezet, vagyis 100 m sugarú körön belül az erdők élőhelyi értékelését is elvégeztük. Vizuális becslés alapján minőségi osztályokba soroltuk az erdőállományt a faállomány átlagkora, az elegyesség, az odvak és egyéb denevérbúvóhelyek megléte és a holtfa mennyisége alapján. Az egyes osztályok az ökológiai minőség javulásával emelkedő pontszámokat kaptak. 
2. táblázat: Az erdők élőhelyi értékeire adott pontszámok.

Table 2: Calculation of habitat naturalness values

\begin{tabular}{|l|c|c|c|c|c|c|}
\hline DENEVÉRBÚVÓHELYEK SZÁMA & 0 & $1-5$ & $6-20$ & $21-50$ & $50<$ & $\mathrm{db} / \mathrm{ha}$ \\
\cline { 2 - 8 } (odvak, hasadékok, kéregüregek) & 1 & 2 & 3 & 4 & 5 & pont \\
\hline
\end{tabular}

\begin{tabular}{|l|c|c|c|c|c|c|}
\hline HOLTFA JELENLÉTE & 0 & $1-5$ & $6-20$ & $21-50$ & $50<$ & $\mathrm{db} / \mathrm{ha}$ \\
\cline { 2 - 7 } $\begin{array}{l}\text { (min. } 10 \text { cm mellmagassági átmé- } \\
\text { rójü álló vagy fekvő holtfa, ill. olyan } \\
\text { fa, mely legalább 3 m hosszú, 10 } \\
\text { cm-nél vastagabb elhalt ággal ren- } \\
\text { delkezik) }\end{array}$ & 1 & 2 & 3 & 4 & 5 & pont \\
\hline
\end{tabular}

\begin{tabular}{|l|c|c|c|c|c|c|}
\hline FAÁLLOMÁNY ELEGYESSÉGE & 0 & $1-2$ & $3-5$ & $6-8$ & $8<$ & $\mathrm{db}$ \\
\cline { 2 - 7 } (őshonos fafajok száma) & 1 & 2 & 3 & 4 & 5 & pont \\
\hline
\end{tabular}

\begin{tabular}{|ll|c|c|c|c|c|c|}
\hline FAÁLLOMÁNY & kemény lomb & $0-25$ & $26-50$ & $51-80$ & $81-110$ & $110<$ & \multirow{2}{*}{ év } \\
\hline KORA & lágy lomb & $0-20$ & $21-40$ & $41-70$ & $71-90$ & $90<$ & \\
\cline { 2 - 9 } (mértékadó állományrész átlagkora) & 1 & 2 & 3 & 4 & 5 & pont \\
\hline
\end{tabular}

Plusz 1-1 pontot adtunk az alábbi esetekben:

- természetközeli cserjés erdőszegély,

- természetes cserjeszint állományban,

- böhöncök, öreg tanúfák az erdöben,

- változatos és természetközeli korosztályviszonyok az erdőben,

- természetes lékek, helyenként ligetesedő foltok.

A pontokat összegezve és elosztva 5 -tel kaptuk meg az élőhely átlagos pontszámát. A végső átlag pontszám alapján legvégül a következő élőhelyi minősítést adtuk az erdőnek:

3. táblázat: Az erdők élőhelyi minősitésének kategóriái.

Table 3: Categories of habitat assessment

\begin{tabular}{|c|c|}
\hline Élőhelyi minősités & Végső átlagos pontszám \\
\hline Kevéssé jó élőhely & $0,8-2$ \\
\hline Átlagos élőhely & $2,2-3$ \\
\hline Jó élőhely & $3,2-5$ \\
\hline
\end{tabular}


A 685 mintavételi helyen az élőhelyi minősitések az alábbiak szerint alakultak:

4. táblázat: A mintavételi helyek élőhelyi minőség szerinti eloszlása.

Table 4: Distribution of habitat naturalness classes

\begin{tabular}{|c|c|}
\hline Élőhelyi minősítés & Mintavételi helyek száma (db) \\
\hline Kevéssé jó élőhely & 102 \\
\hline Átlagos élőhely & 251 \\
\hline Jó élőhely & 332 \\
\hline
\end{tabular}

Ezek az arányok természetesen nem az erdők általános élőhelyi jóságát tükrözik, hiszen az, hogy a jó élőhelyek számaránya ilyen magas, csak azt mutatja, hogy a felmérés során igyekeztünk minél több természetvédelmi szempontból értékes erdőt felmérni, s ezért a detektorok nagyobb arányban kerültek a jobb erdőkbe, mint a rosszabbakba.

A holtfa tekintetében is osztályoztuk az erdőket a felméréskor adott pontszámoknak megfelelően.

5. táblázat: A holtfa mennyiség szerinti mintavételi eloszlás.

Table 5: Proportion of the deadwood.

\begin{tabular}{|c|c|c|}
\hline Holtfa minősítés & Pontszám & Mintavételi helyek száma (db) \\
\hline Kevés holtfa & $1-2$ & 144 \\
\hline Átlagos mennyiség & 3 & 229 \\
\hline Sok holtfa & $4-5$ & 312 \\
\hline
\end{tabular}

A sok holtfával rendelkező erdők magasabb aránya itt is csak annyit jelent, hogy a felmérés során igyekeztünk minél több természetvédelmi szempontból értékes erdőt felmérni, s ezért a detektorok nagyobb arányban kerültek a több holtfával rendelkező erdőkbe.

Definíciónk szerint „sok holtfával” rendelkezik az erdő, ha a $10 \mathrm{~cm}$-nél vastagabb fekvő és álló holtfa, továbbá a $3 \mathrm{~m}$-nél hosszabb és $10 \mathrm{~cm}$-nél vastagabb elhalt ágakkal rendelkező fák összes mennyisége meghaladja a $20 \mathrm{db} /$ ha értéket. Ezt az értéket a középkorú és idős erdők könnyen elérik, ha a nevelővágásokat, az egyéb termeléseket és az egészségügyi termeléseket legalább 2 tíz éves erdőtervi ciklusig mellőzzük. A 2-5 évtizednyi pihentetés után kialakult holtfa mennyiség már kedvezőnek mondható (Bölöni \& Ódor 2014), s ezt az állapotot a természetvédelmi rendeltetésű erdők többségében szükséges volna elérni.

A denevérek aktivitását minden megfigyelési pontra meghatároztuk összes denevérre illetve minden denevércsoportra külön-külön. Az aktivitás mérőszáma a hangfájlok darabszáma volt. Az egyes területeken előforduló denevérfajok összetétele alapján 4 külön területi egységet hoztunk létre, melyek az alábbiak:

I. Börzsöny: Központi-Börzsöny, Börzsönyi-peremhegység, Börzsönyi kismedencék, Nógrádi-medence, Visegrádi-Dunakanyar, Kosdi-dombság, Alsó-Ipoly-völgy 
II. Kiskunság: Solti-sík, Kiskunsági-homokhát, Pilis-Alpári-homokhát, Dél-Tisza-völgy, Csepeli-sík

III. Nagykunság: Jászság, Hatvani-sík, Dél-Nyírség, Szatmári-sík, Északkelet-Nyírség, Közép-Nyírség, Délkelet-Nyírség

IV. Körösök vidéke: Kis-Sárrét, Körösmenti-sík

Az aktivitási mérőszámokat 3 gyakorisági kategóriába soroltuk, úgymint sok, átlagos vagy kevés denevér. Minden területi egységre külön kellett meghatározzuk a gyakorisági kategóriákhoz tartozó egyedsürüség értékhatárokat, hiszen területenként egyes denevérfajoknak vagy akár denevércsoportoknak is jelentősen más volt a populáció nagysága. A kategóriák értékhatárait úgy határoztuk meg, hogy egy adott területegységen belül lehetöleg közel azonos mintaszámmal szerepeljen mindhárom gyakorisági kategória. Ez azért volt fontos, hogy a kontingenciavizsgálat feltételei teljesülhessenek. A statisztikai próbához a területegységek gyakorisági kategória értékeit összevontuk, $s$ a tesztet a teljes adatbázisra végeztük el.

Annak megállapitására, hogy az erdők élöhelyi minősitése szerint a denevérek várható gyakorisági értékei és a valós eloszlása között van-e szignifikáns eltérés, a függetlenségvizsgálatot khi-négyzet próbával vizsgáltuk. Az elemzéshez 3×3-as kontingenciatáblát állítottunk fel, ahol az egyik változó a denevérek gyakorisági kategóriája, a másik változó pedig az élőhelyet minősitő osztályozás volt. A maximálisan méltányolható első fajta hibát 1\%-ban állapítottuk meg. A nullhipotézis szerint a két vizsgált változó független egymástól. A Szabadsági fok: $D F=($ a sorok száma -1$)$ szorozva (az oszlopok száma -1$)=4$. A kritikus érték: 13,28 .

\section{EREDMÉNYEK ÉS MEGVITATÁSUK}

\section{Denevérfaunisztikai eredmények}

A 685 mintavételi ponton összesen 82870 denevérhangot tartalmazó hangfájt azonosítottunk. Ez annyit tesz, hogy egy éjszaka alatt átlagban 121 db értékelhetö hangfájlt rögzítettek a müszerek.

A fotóeljárással kiegészített hangelemző fajhatározással összesen 23 denevérfajt sikerült a területen kimutatnunk. A 23 denevérfajból 5 fokozottan védett, 8 faj pedig közösségi jelentőségü. A Rhinolophus hipposideros és a Myotis alcathoe csak hegyvidéken fordult elö, de minden más faj az Alföldröl is elökerült. Az egyes fajok beazonositása az általunk kifejlesztett ultrahangdetektorral és a hozzá csatolt számítógépes elemző programmal történt. A Vespertilio és a Pipistrellus nemzetségekhez tartozó fajok kivételével minden denevérfajról sikerült fajhatározásra alkalmas röpképet is készítenünk. 
6. táblázat: A vizsgálat során megfigyelt denevérfajok.

Table 6: Bat species recorded during the study.

\begin{tabular}{|c|c|c|c|}
\hline Faj tudományos neve & Magyar név & $\begin{array}{l}\text { Országos } \\
\text { védettségi } \\
\text { szint }\end{array}$ & $\begin{array}{l}\text { Európai Uniós } \\
\text { besorolás }\end{array}$ \\
\hline $\begin{array}{l}\text { Rhinolophus ferrumequinum (Schre- } \\
\text { ber, 1774) }\end{array}$ & $\begin{array}{c}\text { nagy patkósorrú } \\
\text { denevér }\end{array}$ & $\begin{array}{l}\text { fokozottan } \\
\text { védett }\end{array}$ & $\begin{array}{l}\text { közösségi } \\
\text { jelentöségű }\end{array}$ \\
\hline $\begin{array}{l}\text { Rhinolophus hipposideros } \\
\text { (Bechstein, 1800) }\end{array}$ & $\begin{array}{c}\text { kis patkósorrú } \\
\text { denevér }\end{array}$ & védett & $\begin{array}{l}\text { közösségi } \\
\text { jelentőségű }\end{array}$ \\
\hline $\begin{array}{l}\text { Barbastella barbastellus (Schreber, } \\
\text { 1774) }\end{array}$ & pisze denevér & $\begin{array}{c}\text { fokozottan } \\
\text { védett }\end{array}$ & $\begin{array}{l}\text { közösségi } \\
\text { jelentőségű }\end{array}$ \\
\hline $\begin{array}{l}\text { Eptesicus serotinus (Schreber, } \\
\text { 1774) }\end{array}$ & kései denevér & védett & \\
\hline $\begin{array}{l}\text { Myotis alcathoe (von Helversen \& } \\
\text { Heller, 2001) }\end{array}$ & nimfa denevér & védett & \\
\hline Myotis bechsteinii (Kuhl, 1817) & nagyfülü denevér & $\begin{array}{c}\text { fokozottan } \\
\text { védett }\end{array}$ & $\begin{array}{l}\text { közösségi } \\
\text { jelentőségű }\end{array}$ \\
\hline Myotis blythii (Tomes, 1857) & hegyesorrú denevér & védett & $\begin{array}{l}\text { közösségi } \\
\text { jelentöségű }\end{array}$ \\
\hline Myotis brandtii (Eversmann, 1845) & Brandt-denevér & védett & \\
\hline Myotis dasycneme (Boie, 1825) & tavi denevér & $\begin{array}{c}\text { fokozottan } \\
\text { védett }\end{array}$ & $\begin{array}{l}\text { közösségi } \\
\text { jelentőségű }\end{array}$ \\
\hline Myotis daubentonii (Kuhl, 1817) & vízi denevér & védett & \\
\hline Myotis emarginatus (Geoffroy, 1806) & csonkafülü denevér & $\begin{array}{c}\text { fokozottan } \\
\text { védett }\end{array}$ & $\begin{array}{l}\text { közösségi } \\
\text { jelentőségű }\end{array}$ \\
\hline Myotis myotis (Borkhausen, 1797) & $\begin{array}{l}\text { közönséges } \\
\text { denevér }\end{array}$ & védett & $\begin{array}{l}\text { közösségi } \\
\text { jelentőségű }\end{array}$ \\
\hline Myotis mystacinus (Kuhl, 1817) & bajuszos denevér & védett & \\
\hline Myotis nattereri (Kuhl, 1817) & $\begin{array}{c}\text { horgasszőrü } \\
\text { denevér }\end{array}$ & védett & \\
\hline Nyctalus leisleri (Kuhl, 1817) & szőröskarú denevér & védett & \\
\hline Nyctalus noctula (Schreber, 1774) & korai denevér & védett & \\
\hline Pipistrellus kuhlii (Kuhl, 1817) & fehérszélü denevér & védett & \\
\hline $\begin{array}{l}\text { Pipistrellus nathusii (Keyserling \& } \\
\text { Blasius, 1839) }\end{array}$ & $\begin{array}{c}\text { durvavitorlájú } \\
\text { denevér }\end{array}$ & védett & \\
\hline $\begin{array}{l}\text { Pipistrellus pipistrellus (Schreber, } \\
\text { 1774) }\end{array}$ & törpe denevér & védett & \\
\hline Pipistrellus pygmaeus (Leach, 1825) & $\begin{array}{c}\text { szoprán } \\
\text { törpedenevér }\end{array}$ & védett & \\
\hline Plecotus auritus (Linnaeus, 1758) & $\begin{array}{l}\text { barna hosszúfülü- } \\
\text { denevér }\end{array}$ & védett & \\
\hline Plecotus austriacus (Fischer, 1829) & $\begin{array}{l}\text { szürke hosszúfülü- } \\
\text { denevér }\end{array}$ & védett & \\
\hline Vespertilio murinus (Linnaeus, 1758) & fehértorkú denevér & védett & \\
\hline
\end{tabular}




\section{A denevérek aktivitása és az erdők kapcsolata}

Első hipotézisünk szerint az erdő több élőhelyi tényezőből adódó természetességi mutatója és a denevérek aktivitása között szoros kapcsolat van. Második felállitott hipotézisünk pedig az, hogy a holtfa mennyisége már önmagában is összefüggésben van a denevérek egyedsürüségével, aktivitásával.

a) Az erdő természetességi mutatója szerinti vizsgálat

A statisztikai próbát elöször az összes denevérre, majd külön-külön az egyes fajcsoportokra is elvégeztük. A Rhinolophus-csoportra külön nem végeztük el a próbát, mert ennél a csoportnál olyan kicsi volt az elemszám, hogy rá a statisztikai próba nem volt alkalmazható. A 7. táblázatban a számok a mért gyakorisági értékeket, a zárójelben lévő számok pedig a várható gyakorisági értékeket mutatják.

7a. táblázat: Az összes denevér gyakorisági eloszlása az élőhelyi minőség függvényében.

\begin{tabular}{|c|c|c|c|c|}
\hline \multirow{2}{*}{ DENEVÉR $\downarrow$} & \multicolumn{3}{|c|}{ ÉLŐHELY } \\
\cline { 3 - 5 } & sok & $132(107)$ & $73(81)$ & $16(33)$ \\
\hline \multirow{3}{*}{ SZUM } & átlagos & gyenge \\
\cline { 2 - 5 } & átlagos & $108(109)$ & $79(82)$ & $38(34)$ \\
\cline { 2 - 5 } & kevés & $92(116)$ & $99(88)$ & $48(36)$ \\
\hline & $X 2:$ & \multicolumn{3}{c|}{ kritikus érték: } \\
& 26,74 & $>$ & 13,28
\end{tabular}

van szignifikáns eltérés

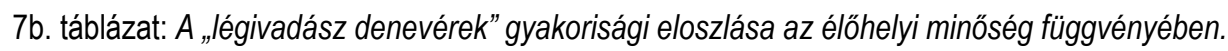

\begin{tabular}{|c|c|c|c|c|}
\hline \multirow{2}{*}{ DENEVÉR $\downarrow$} & \multicolumn{3}{|c|}{ ÉLŐHELY } \\
\cline { 3 - 5 } & jó & átlagos & gyenge \\
\hline \multirow{4}{*}{ légiv. } & sok & $109(103)$ & $82(78)$ & $22(32)$ \\
\cline { 2 - 5 } & átlagos & $107(108)$ & $75(82)$ & $41(33)$ \\
\cline { 2 - 5 } & kevés & $116(121)$ & $94(91)$ & $39(37)$ \\
\hline
\end{tabular}

$X 2$ : $\quad$ kritikus érték:

$6,26<13,28$

nincs szignifikáns eltérés 
7c. táblázat: A Barbastella csoport gyakorisági eloszlása az élőhelyi minőség függvényében.

\begin{tabular}{|c|c|c|c|c|}
\hline \multirow{2}{*}{ DENEVÉR $\downarrow$} & \multicolumn{3}{|c|}{ ÉLŐHELY } \\
\cline { 3 - 5 } & jó & átlagos & gyenge \\
\hline \multirow{3}{*}{ BARB } & sok & $138(99)$ & $56(75)$ & $11(31)$ \\
\cline { 2 - 5 } & átlagos & $77(86)$ & $66(65)$ & $34(26)$ \\
\cline { 2 - 5 } & kevés & $117(147)$ & $129(111)$ & $57(45)$ \\
\hline \multicolumn{3}{|c}{ X2: } & \multicolumn{4}{c}{ kritikus érték: } \\
\multicolumn{2}{|c|}{47,63} & $>$ & 13,28
\end{tabular}

van szignifikáns eltérés

7d. táblázat: A Myotis csoport gyakorisági eloszlása az élőhelyi minőség függvényében.

\begin{tabular}{|c|c|c|c|c|}
\hline \multirow{2}{*}{ DENEVÉR $\downarrow$} & \multicolumn{3}{|c|}{ ÉLŐHELY } \\
\cline { 3 - 5 } & jó & átlagos & gyenge \\
\hline \multirow{3}{*}{ MYO } & sok & $138(107)$ & $72(81)$ & $10(33)$ \\
\cline { 2 - 5 } & átlagos & $97(107)$ & $87(81)$ & $36(33)$ \\
\cline { 2 - 5 } & kevés & $97(119)$ & $92(90)$ & $56(36)$ \\
\hline
\end{tabular}

2: $\quad$ kritikus érték:

$42.14>13,28$

van szignifikáns eltérés

7e. táblázat: A Pipistrellus csoport gyakorisági eloszlása az élöhelyi minőség függvényében.

\begin{tabular}{|c|c|c|c|c|}
\hline \multirow{2}{*}{ DENEVÉR $\downarrow$} & \multicolumn{3}{|c|}{ ÉLÖHELY } \\
\cline { 3 - 5 } \multicolumn{2}{|c|}{} & jó & átlagos & gyenge \\
\hline \multirow{4}{*}{ PIP } & $131(108)$ & $71(81)$ & $20(33)$ \\
\cline { 2 - 5 } & átlagos & $105(108)$ & $86(81)$ & $31(33)$ \\
\cline { 2 - 5 } & kevés & $96(117)$ & $94(88)$ & $51(36)$ \\
\hline
\end{tabular}

X2: $\quad$ kritikus érték:

$22,46>13,28$

van szignifikáns eltérés 
7f. táblázat: A Plecotus csoport gyakorisági eloszlása az élőhelyi minőség függvényében.

\begin{tabular}{|c|c|c|c|c|}
\hline \multirow{2}{*}{ DENEVÉR $\downarrow$} & \multicolumn{3}{|c|}{ ÉLŐHELY } \\
\cline { 3 - 5 } & jó & átlagos & gyenge \\
\hline \multirow{3}{*}{ PLE } & $137(104)$ & $61(79)$ & $17(32)$ \\
\cline { 2 - 5 } & átlagos & $91(110)$ & $97(83)$ & $38(34)$ \\
\cline { 2 - 5 } & kevés & $104(118)$ & $93(89)$ & $47(36)$ \\
\hline \multicolumn{3}{|c|}{ X2 : } & \multicolumn{3}{c}{ kritikus érték: } \\
& 32,5 & $>$ & \multicolumn{2}{c}{13,28}
\end{tabular}

van szignifikáns eltérés

b) A holtfa mennyisége szerinti vizsgálat

A statisztikai próbát itt is először az összes denevérre, majd külön-külön az egyes fajcsoportokra is elvégeztük. A 8. táblázatban a számok a mért gyakorisági értékeket, a zárójelben lévő számok pedig a várható gyakorisági értékeket mutatják.

8a. táblázat: Az összes denevér gyakorisági eloszlása a holtfa mennyiségének függvényében.

\begin{tabular}{|c|c|c|c|c|}
\hline \multirow{2}{*}{ DENEVÉR $\downarrow$} & \multicolumn{3}{|c|}{ HOLTFA } \\
\cline { 3 - 5 } & sok & átlagos & kevés \\
\hline \multirow{3}{*}{ SZUM } & sok & $123(101)$ & $67(74)$ & $31(46)$ \\
\cline { 2 - 5 } & átlagos & $102(102)$ & $77(75)$ & $46(47)$ \\
\cline { 2 - 5 } & kevés & $87(109)$ & $85(80)$ & $67(50)$ \\
\hline \multicolumn{3}{|c|}{ X2 : } & \multicolumn{3}{c}{ kritikus érték: } \\
\multicolumn{2}{|c|}{21,13} & $>$ & 13,28
\end{tabular}

van szignifikáns eltérés 
8b. táblázat: $A$ „légivadász denevérek” gyakorisági eloszlása a holtfa mennyiségének függvényében.

\begin{tabular}{|c|c|c|c|c|}
\hline \multirow{2}{*}{\multicolumn{2}{|c|}{ DENEVÉR $\downarrow$}} & \multicolumn{3}{|c|}{ HOLTFA } \\
\hline & & \multirow{2}{*}{$\begin{array}{c}\text { sok } \\
96(97)\end{array}$} & \multirow{2}{*}{$\frac{\text { átlagos }}{77(71)}$} & \multirow{2}{*}{$\begin{array}{l}\text { kevés } \\
40(45)\end{array}$} \\
\hline \multirow{3}{*}{ légi } & sok & & & \\
\hline & átlagos & $110(102)$ & $67(75)$ & $46(47)$ \\
\hline & kevés & $106(113)$ & $85(83)$ & $58(52)$ \\
\hline
\end{tabular}

$X 2$ : kritikus érték:

$3,6<13,28$

nincs szignifikáns eltérés

8c. táblázat: A Barbastella csoport gyakorisági eloszlása a holtfa mennyiségének függvényében.

\begin{tabular}{|c|c|c|c|c|}
\hline \multirow{2}{*}{ DENEVÉR $\downarrow$} & \multicolumn{3}{c|}{ HOLTFA } \\
\cline { 3 - 5 } & sok & $126(93)$ & $63(69)$ & $16(43)$ \\
\hline \multirow{4}{*}{ BARB } & átlagos & $75(81)$ & $68(59)$ & $34(37)$ \\
\cline { 2 - 5 } & kevés & $111(138)$ & $98(101)$ & $94(64)$ \\
\hline \multicolumn{3}{|c|}{ X2 : } & \multicolumn{3}{c|}{ kritikus érték: } \\
& 50,68 & $>$ & 13,28
\end{tabular}

van szignifikáns eltérés

8d. táblázat: A Myotis csoport gyakorisági eloszlása a holtfa mennyiségének függvényében.

\begin{tabular}{|c|c|c|c|c|}
\hline \multirow{2}{*}{ DENEVÉR $\downarrow$} & \multicolumn{3}{|c|}{ HOLTFA } \\
\cline { 3 - 5 } \multicolumn{2}{|c|}{} & sok & átlagos & kevés \\
\hline \multirow{4}{*}{ MYO } & sok & $130(100)$ & $63(74)$ & $27(46)$ \\
\cline { 2 - 5 } & átlagos & $92(100)$ & $84(74)$ & $44(46)$ \\
\cline { 2 - 5 } & kevés & $90(112)$ & $82(82)$ & $73(52)$ \\
\hline
\end{tabular}

$X 2$ : kritikus érték:

$33.8>13,28$

van szignifikáns eltérés 
8e. táblázat: A Pipistrellus csoport gyakorisági eloszlása a holtfa mennyiségének függvényében.

\begin{tabular}{|c|c|c|c|c|}
\hline \multirow{2}{*}{\multicolumn{2}{|c|}{ DENEVÉR $\downarrow$}} & \multicolumn{3}{|c|}{ HOLTFA } \\
\hline & & \multirow{2}{*}{$\begin{array}{c}\text { sok } \\
122(101)\end{array}$} & \multirow{2}{*}{$\begin{array}{l}\text { átlagos } \\
64(74)\end{array}$} & \multirow{2}{*}{$\begin{array}{l}\text { kevés } \\
36(47)\end{array}$} \\
\hline \multirow{3}{*}{ PIP } & sok & & & \\
\hline & átlagos & $98(101)$ & $83(74)$ & $41(47)$ \\
\hline & kevés & $92(110)$ & $82(81)$ & $67(51)$ \\
\hline \multicolumn{3}{|c|}{$x^{2}$} & \multicolumn{2}{|c|}{ kritikus érték: } \\
\hline & 18,15 & $>$ & \multicolumn{2}{|c|}{13,28} \\
\hline
\end{tabular}

van szignifikáns eltérés

8f. táblázat: A Plecotus csoport gyakorisági eloszlása a holtfa mennyiségének függvényében.

\begin{tabular}{|c|c|c|c|c|}
\hline \multirow{2}{*}{ DENEVÉR $\downarrow$} & \multicolumn{3}{|c|}{ HOLTFA } \\
\cline { 3 - 5 } & & sok & átlagos & kevés \\
\hline \multirow{4}{*}{ PLE } & sok & $130(98)$ & $62(72)$ & $23(45)$ \\
\cline { 2 - 5 } & átlagos & $88(103)$ & $90(76)$ & $48(48)$ \\
\cline { 2 - 5 } & kevés & $94(111)$ & $77(82)$ & $73(51)$ \\
\hline \multicolumn{3}{|c|}{$X^{2}:$} & \multicolumn{3}{c|}{ kritikus érték: } \\
\multicolumn{2}{|c|}{39,78} & $>$ & \multicolumn{2}{c|}{13,28}
\end{tabular}

van szignifikáns eltérés

c) A kapott eredmények összegzése

A statisztikai próbák eredményeit a 9. táblázatban összesítettük. A homogenitás vizsgálat szerint 1\%-os hibahatár mellett az összes denevérre kiszámított gyakorisági eloszlás szignifikáns eltérést igazol az élőhely és a holtfa tekintetében is. Pozitív a korreláció, vagyis esetünkben azt jelenti, hogy jobb élöhelyen nagyobb, rosszabb élőhelyen pedig kisebb a denevérek aktivitása. 
9. táblázat: Az élőhely és a holtfa alapján történő homogenitás vizsgálat összesitett eredményei 99\%-os kontingenciaszinten. (A légivadász csoportnál 5\%-os méltányolható hiba esetén sincs szignifikáns eltérés).

\begin{tabular}{|c|c|c|}
\hline \multirow{2}{*}{$\begin{array}{c}\text { DENEVÉR CSOPORT } \\
\text { (rövidítés) }\end{array}$} & \multicolumn{2}{|c|}{ SZIGNIFIKÁNS ELTÉRÉS } \\
\cline { 2 - 3 } & ÉLÖHELY & HOLTFA \\
\hline Összes denevér (SZUM) & van & van \\
\hline Légivadász csoport (légi) & nincs & nincs \\
\hline Pipistrellus csoport (PIP) & van & van \\
\hline Myotis csoport (MYO) & van & van \\
\hline Barbastella csoport (BARB) & van & van \\
\hline Plecotus csoport (PLE) & van & van \\
\hline
\end{tabular}

A különböző denevércsoportokat vizsgálva azt látjuk, hogy a „légivadász csoport” esetében azonban még az 5\%-os hibahatár mellett sem mutatható ki a korreláció. Ez minden bizonnyal azért van, mert az ebbe a csoportba tartozó Nyctalus, Eptesicus és Vespertilio fajok legföképpen nyilt területek fölött vadásznak. Alacsony ultrahang frekvenciájuk az akadálymentes, nyílt téri vadászatra specializálódott. Ezek a fajok viszonylag nagy távolságból képesek felmérni a zsákmányállatot, de a fatörzsekkel és a lombkoronával besürüsödött légterekben ez a tudás nem érvényesül. A közeli prédák pontos beméréséhez a magasabb frekvenciájú és a gyors ismétlődésű hangimpulzusok a legalkalmasabbak, melyek - mint tanulmányunkban már láthattuk -, a többi denevércsoportra jellemző igazán. A légivadász csoport tagjai a nyilt téren vadászva leggyakrabban olyan élőhelyeken (üres vágásterületek, erdőfelújitások és fiatalosok felett) fordultak elő, ahol kevés volt a holtfa és az összesitett élőhelyi értékek is kedvezőtlenek voltak.

A többi denevércsoport gyakorisága esetében már egyértelmü és nagyon szoros pozitív korreláció mutatható ki az élőhely minősége és a holtfa mennyisége szerint is. Ezek a fajok a rövidtávú, de nagyon aprólékos, jól kifinomult zsákmányfelismerésre specializálódtak. Frekvenciamodulált ultrahangjuk elsősorban a változatos mintázatú erdőszegélyben, lombkoronában, cserjésben és gyepvegetációban történő kutatásra a legalkalmasabb. A jó élöhelyekhez és a sok holtfához történő kötődés valószínüleg annak a jele, hogy ezekben az erdőkben, a vegetációs időben mindig nagy mennyiségü, változatos táplálékbázist találnak maguknak, továbbá sok búvóhely is rendelkezésre áll számukra (Frank 2000; Csóka 2013). Különösen kölyöknevelés időszakában e két feltétel, - vagyis a megfelelő táplálékmennyiség és alkalmas búvóhelyek megfelelő száma -, elengedhetetlen feltétele annak, hogy a populáció fennmaradhasson. A holtfa számos üreget biztosít a denevéreknek, de a holtfában megtelepedő nagyszámú szaprofág és szaproxylofág rovar révén gazdag táplálékbázist is nyújt közvetlenül a bőregereknek. Közvetett módon pedig a harkályokon keresztül segíti a 
holtfa a denevéreket. A fakopáncsok ugyanis jelentős részben holtfához kötődnek táplálkozásuk révén, ezek a madarak pedig odvakat ácsolnak, melyek később a denevérek lakhelyeivé válnak.

A fokozottan védett és a nemzetközi jelentőségü denevérfajok azokhoz a denevércsoportokhoz tartoznak, melyeknél kimutatható volt holtfához és a jó erdei élőhelyekhez való kötődés, éppen ezért kijelenthetjük, hogy a jó élőhelyi adottságokkal rendelkező és a holtfában gazdag erdők természetvédelmi szempontból kiemelt jelentőséggel bírnak. Az ilyen kimagasló ökológiai értékkel rendelkező erdők gyarapítása védett természeti területeken és Natura 2000 területeken nagyon fontos feladatunk.

\section{ERDŐKEZELÉSI JAVASLATOK}

Az erdők élőhelyi minőségének romlása, a holtfa mennyiségének mértéktelen csökkenése túlnyomórészt olyankor következik be, amikor túlzott mértékü erdőgazdálkodási beavatkozás éri az erdőt. Az erdészeti beavatkozások mértéke és minősége azonban rajtunk, erdőgazdálkodókon és a szakmai munkát ellenőrző hatóságokon múlik. Valójában nem kellene mást tennünk, csak egy kicsit nagyobb teret engednünk az erdöben zajló természetes folyamatoknak. Ha az erdőállomány nevelése során időt és teret hagyunk néhány igen fontos önszabályozó folyamatnak, akkor ezek az erdö ökológiai állapotát gyorsan és látványosan javitják. Ha az erdő fejlődése elmozdul a természetes állapot irányába, azzal nő a faállomány ellenálló és regenerálódó képessége, s mindezzel együtt gyakran az értékkihozatal is javul. Elsősorban a természetes felújulás által nyújtott faji sokszínűség biztosítására, az öngyérülési folyamatok bizonyos fokú szabaddá tételére, az odvas, böhöncös, törött, korhadt, hasadt fák megfelelő számban történő visszahagyására, az erdőszegélyek és a cserjeszint megóvására, továbbá az öreg erdők szükséges területarányban történő fenntartására kell kiemelt figyelmet fordítanunk különösen a természetvédelmi és a Natura 2000 rendeltetésű erdőkben! Ez természetesen nem azt jelenti, hogy magára kellene hagyni az erdőt, hiszen ésszerü beavatkozásokra gyakorlatilag mindenütt szükség van. Különösen olyan kedvezőtlen termőhelyi és egyéb környezeti tényező mellett van szükség rendszeres kezelésre, ahol az intenzíven terjedő növényfajok akadályozzák a természetközeli erdőállapotok kialakulását.

\section{KÖSZÖNETNYILVÁNÍTÁS}

A felmérő munkáink elsősorban az erdőtervezéshez, a Natura 2000 fenntartási tervek és a természetvédelmi területek kezelési terveinek készítéséhez biztosítottak fontos biotikai adatokat. Erre a munkára az illetékes nemzeti park igazgatóságok kértek fel bennünket, s 
többnyire ök nyújtották a kutatáshoz szükséges anyagi fedezetet is. Köszönjük a KörösMaros Nemzeti Park Igazgatóságnak, a Kiskunsági Nemzeti Park Igazgatóságnak és a Hortobágyi Nemzeti Park Igazgatóságnak, hogy lehetővé tették kutatásainkat, s javaslataikkal segitettek bennünket. Külön köszönjük mindazoknak a támogatását, akik a terepi munkákban is alkalmanként velünk voltak. Külön hálával tartozunk Máté Rudolfnak, Szelényi Balázsnak, Bota Viktóriának, Bánfi Péternek, Bíró Istvánnak, Szabó Gyulának és Habarics Bélának, akik a felmérés előkészítő fázisában igen hasznos munkát végeztek. Köszönet illeti Balogh Lászlót és Német Attilát, akik a technikai eszközök fejlesztésében jeleskedtek. Végül pedig, de legföképpen köszönjük Utasi Gabriella támogatását, aki a terepi munkában és az akusztikai adatok elemzésében is pótolhatatlan segítséget nyújtott.

\section{FELHASZNÁLT IRODALOM}

Ahlén I. 1981: Identification of Scandinavian Bats by their sounds. The Swedish University of Agricultural Sciences, Department of Wildlife Ecology, Uppsala.

Ahlén I. \& Baagoe H.J. 1999: Use of ultrasound detectors for bat studies in Europe: experiences from field identification surveys, and monitoring. Acta Chiropterologica 1(2): 137-150.

Barataud M. 2015: Acoustic ecology of European bats. Biotope \& National Museum of Natural History, Paris.

Bölöni J. \& Ódor P. 2014: A holtfa mennyisége a mérsékelt övi erdőkben. In: Csóka Gy. \& Lakatos F. (szerk.): A holtfa. Silva Naturalis 5, Nyugat-magyarországi Egyetem Kiadó, Sopron, 203-217.

Csóka Gy. 2013: A természetesség hatása az erdők egészségi állapotára. In: Bartha D. \& Puskás L. (szerk.): Silva Naturalis 1. A folyamatos erdőboritás fenntartása melletti erdőgazdálkodás alapjai. Nyugat-magyarországi Egyetem Kiadó, Sopron, 43-57.

Csősz I. \& Szodoray-Parádi F. 2009: Időnyújtásos ultrahang-detektorok alkalmazása a magyarországi denevérfaunisztikai kutatásokban. In: Görföl T., Estók P. \& Molnár V. (szerk.): A VII. Magyar Denevérvédelmi Konferencia kiadványa. BEKE \& MDBK, Eger, 15-18.

Dietz C. \& Kiefer A. 2014: Die Fledermäuse Europas - kennen, bestimmen, schützen. Kosmos Naturführer, Stuttgart.

Entwistle A. C., Racey P.A. \& Speakman J.R. 1996: Habitat exploitation by a gleaning bat, Plecotus auritus. Phil. Trans. R. Soc. Lond. B 351(1342): 921-931. DOI: 10.1098/rstb.1996.0085

Estók P. \& Görföl T. 2009: Erdölakó denevér együttesek kutatása, különös tekintettel a Nyctalus lasiopterusra - egy 2009-es EUROBATS projekt előzetes eredményei. In: Görföl T., Estók P. \& Molnár V. (szerk.): A VII. Magyar Denevérvédelmi Konferencia kiadványa. BEKE \& MDBK, Eger, 53-60.

Fenton M.B. \& Bell G.P. 1981: Recognition of species of insectivorous bats by their echolocation calls. Journal of Mammalogy 62(2): 233-243. DOI: 10.2307/1380701

Frank T. (szerk.) 2000: Természet - Erdő - Gazdálkodás. MME \& Pro Silva Hungaria Egyesület, Eger.

Griffin D.R., Webster F.A. \& Michael C.R. 1960: The echolocation of flying insects by bats. Animal Behaviour 8(3-4): 141-154. DOI: $10.1016 / 0003-3472(60) 90022-1$

Jensen M.E. \& Miller L.A. 1999: Echolocation signals of the bat Eptesicus serotinus recorded using a vertical microphone array: effect of flight altitude on searching signals. Behavioral Ecology and Sociobiology 47(12): 60-69. DOI: $10.1007 / \mathrm{s} 002650050650$

Jones G. 1995: Flight performance, echolocation and foraging behavior in noctule bats Nyctalus noctula. Journal of Zoology 237(2): 303-312. DOI: 10.1111/j.1469-7998.1995.tb02764.x

Jones G. 1996: Does echolocation constrain the evolution of body size in bats? Symposia of the Zoological Society of London 69: 111-128. 
Jones G. 1999: Scaling of echolocation call parameters in bats. The Journal of Experimental Biology 202: 3359-3367.

Jones G. \& Barratt E.M. 1999: Vespertilio pipistrellus Schreber, 1774 and V. pygmaeus Leach, 1825 (currently Pipistrellus pipistrellus and P. pygmaeus; Mammalia, Chiroptera): proposed designation of neotypes. Bulletin of Zoological Nomenclature 56: 182-186. DOI: 10.5962/bhl.part.23065

Kalko E.K.V. \& Schnitzler H.U. 1989: The echolocation and hunting behavior of Daubenton's bat, Myotis daubentonii. Behavioral Ecology and Sociobiology 24(4): 225-238. DOI: 10.1007/BF00295202

Magura T., Tóthmérész B. \& Bordán Zs. 2000: Effects of nature management practice on carabid assemblages (Coleoptera: Carabidae) in a non-native plantation. Biological Conservation 93(1): 95-102. DOI: 10.1016/S0006-3207(99)00073-7

Obrist M. ., Boesch R. \& Flückiger P.F. 2004: Variability in echolocation call design of 26 Swiss bat species: consequences, limits and options for automated field identification with a synergetic pattern recognition approach. Mammalia 68(4): 307-322. DOI: 10.1515/mamm.2004.030

Ódor P. 2014: A korhadó faanyag szerepe az erdei növények biodiverzitásában. In: Csóka Gy. \& Lakatos F. (szerk.): A holtfa. Silva Naturalis 5, Nyugat-magyarországi Egyetem Kiadó, Sopron, 155-170.

Russo D. \& Jones G. 2002: Identification of twenty-two bat species (Mammalia: Chiroptera) from Italy by analysis of time-expanded recordings of echolocation calls. Journal of Zoology 258(1): 91-103. DOI: 10.1017/S0952836902001231

Szőke K. \& Estók P. 2013: Különböző állapotú erdőrészek denevéregyütteseinek összehasonlítása akusztikus mintavételek alapján. In: Bíró M. (szerk): A XXX. Országos Tudományos Diákköri Konferencia díjazott hallgatóinak dolgozatai. Eger: EKF Líceum Kiadó, 880-895.

Vaughan N., Jones G. \& Harris S. 1997: Identification of British bat species by multivariate analysis of echolocation parameters. Bioacoustics 7(3): 189-207. DOI: 10.1080/09524622.1997.9753331

Waters D. A. \& Jones G. 1995: Echolocation call structure and intensity in five species of insectivorous bats. Journal of Experimental Biology 198: 475-489.

Waters D.A., Rydell J. \& Jones G. 1995: Echolocation call design and limits on prey size - a case-study using the aerial hawking bat Nyctalus leisleri. Behavioral Ecology and Sociobiology. 37(5): 321-328. DOI: 10.1007/bf00174136

Zsebök S. 2003: Impulzusszámlálás, zajszintkezelés, digitális hangfeldolgozás. In: Molnár V., Orbán É. \& Molnár Z. (szerk.): A II. Magyar Denevérvédelmi Konferencia (Szabadkígyós, 1999. december 4.), a III. Magyar Denevérvédelmi Konferencia (Tokaj, 2001. december 1.) és a IV. Magyar Denevérvédelmi Konferencia (Szögliget, 2003. november 22-23.) kiadványa, Magyar Denevérkutatók Baráti Köre, Budapest, 140-146.

Zsebök S., Estók P. \& Görföl, T. 2012: Acoustic discrimination of Pipistrellus kuhlii and Pipistrellus nathusii (Chiroptera: Vespertilionidae) and its application to assess changes in species distribution. Acta Zoologica Academiae Scientiarum Hungaricae 58(2): 199-209.

Érkezett: 2016. június 19.

Közlésre elfogadva: 2017. november 19. 